ILIJA MIKIĆ

902.2:572.781"652"(497.11)

Institute of Archaeology,

904:726.8"652"(497.11)

Belgrade, Serbia

COBISS.SR-ID 228053516

email:mikicilija@gmail.com

RICARDO ORTEGA-RUIZ

Original research article

Instituto de Formación

Received: June $7^{\text {th }} 2016$

Profesional en Ciencias Forenses,

London, Great Britain

\title{
PALEOPATHOLOGICAL ANALYSIS OF THE INDIVIDUAL 1226-D FROM THE NECROPOLIS OF VIŠE GROBALJA: OSTEOMYELITIS ALONG WITH GREENSTICK FRACTURES AND SURGICAL ANTEMORTEM ACTIVITIES
}

\begin{abstract}
The present paper has the aim to show the results regarding the pathological condition of the individual 1226-D, who was recovered during the archaeological investigations carried out in 1985 at the Više Grobalja necropolis, Viminacium, proceeding from the grave number G-1226. This grave revealed itself to be a mass grave with 4 buried individuals, which were labelled as individuals $A, B, C$ and $D$. The pathological condition of the individual $1226 \mathrm{D}$ is the topic of this work, despite of the fact that, unfortunately, the skeletal remains are incomplete. On one hand, the individual presents an advanced osteomyelitis in the distal left femur showing also a cloaca in the same part of the bone, allowing expel pus and necrotic tissue. On the other hand, both distal radius have been broken as a result of a bending trauma when the individual was young, having as a result greenstick fractures, modifying the regular shape of both wrists, pointing both of them to the medial line.

Also, the left ulna presents an antemortem surgical condition, being probably broken by a blunt force and being removed the bone sharps by a surgeon. Finally, the right femur has been cuted postmortem and removed in some moment after death, probably in recent times..
\end{abstract}

KEYWORDS: PALEOPATHOLOGY, OSTEMYELITIS, AMPUTATION, GREENSTICK FRACTURES, POSTMORTEM CUT, ANTEMORTEM TRAUMA.

\section{INTRODUCTION ${ }^{1}$}

Necropolis Više Grobalja was excavating in year of 1985, but this necropolis is not archaeologicaly completly excavated. Excavations on this location continue to nowadays. This period be-

1 The article results from the project: Viminacium, Roman city and military camp - research of the material and non material culture of inhabitants by using the modern technologies of remote detection, geophysics, GIS, digitalization and $3 D$ visualization (no 47018), funded by The Ministry of Education, Science and Technological Development of the Republic of Serbia. long to second research fase at Viminacium when the thermo power plant Drmno was expanded. Više Grobalja is part of southern necropolis of Viminacium (Mikić, Korać 2013).

On the other hand, numerous skeletons from this necropolis were almost completely anthropologically analyzed. A small number of skeletons are not analyzed and published. Skeleton marked as G-1226D is one of them and presents unique case of paleopathological changes in entire Viminacium. Also, should be mentioned that on this necropolis were buried very different population. 


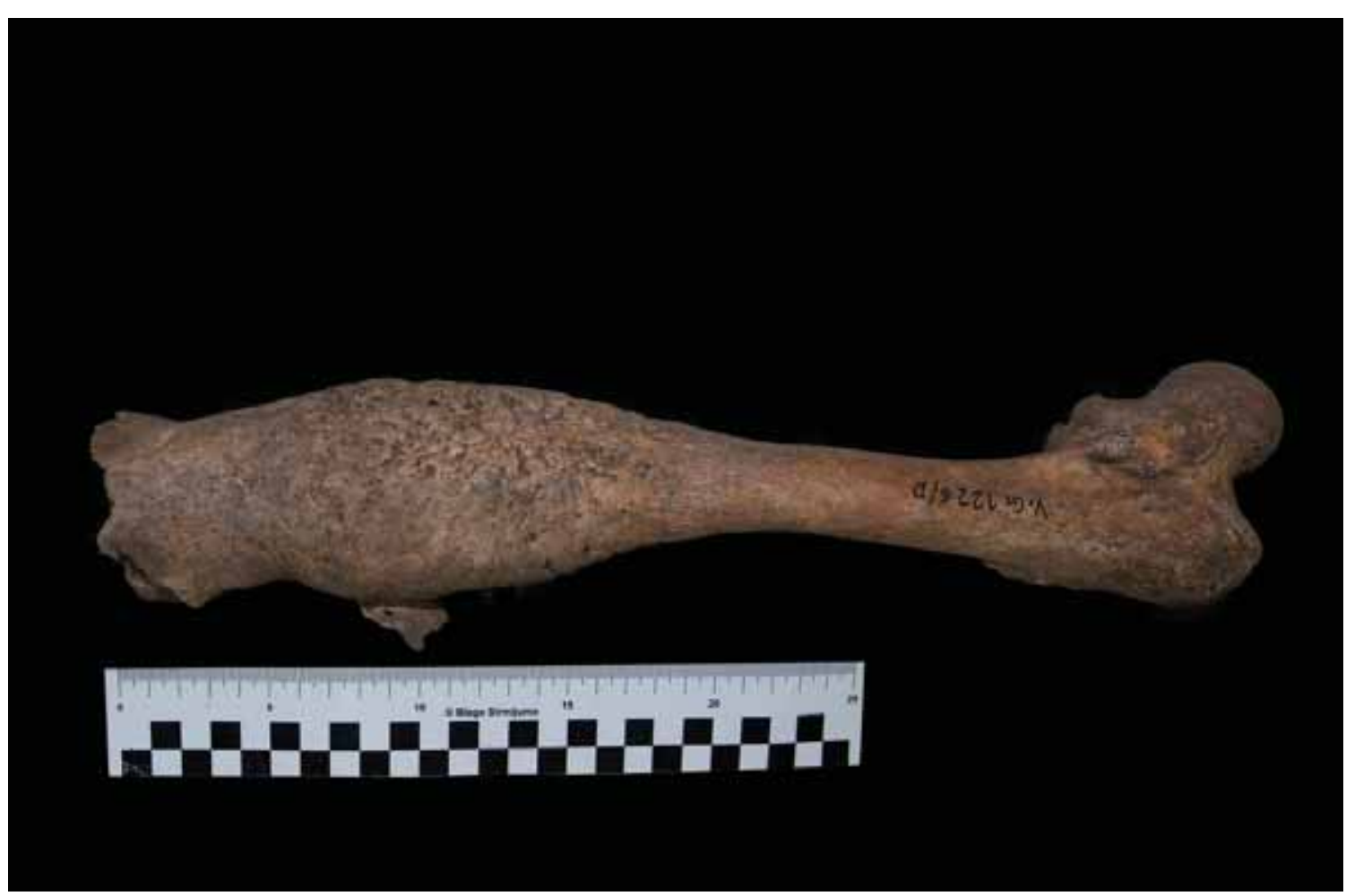

Fig. 1 Left femur with an advances osteomielitis.

Chronologically, grave G-1226D according archaeological finds belong to period from I-V century, but precise dating is unfortunately not possible.

\section{MATERIALS}

This individual was buried underneath the individual $1226 \mathrm{C}$, with an orientation E-W and deviation of $24^{\circ}$. Due to bad preservation conditions and the fact that the skeleton was partially incomplete, the gender could not be determined; even so, the estimated age could be established, that being around 35 years. On the other hand, pathological changes on bones were very well preserved. On this topic, the case of osteomyelitis on the left femoral bone is specially worth mentioning, with a notorious cloaca as a result of the infection.

Regarding the antemortem processes suffered by the individual we can check that on one hand, both radius bones have been broken and healed, thus having the deviation of both to the medial line of the body as a result. In addition, it presents an amputation and an irregular healing in the left ulna, giving the impression that some sort of medical activity was performed, maybe in relation to the broken radius.

\section{METHODS}

In this paper was used two-folded methodology. The first part is so called standardized methodology of an anthropological study of skeletons, concerning gender, individual age. For this part we used criteria defined by D. Ferembach, I. Schwidetzky and M. Stloukal (Ferembach, Schwidetzky and Stloukal). On the other hand, paleopathological changes are identified according criteria of D. J. Ortner (Ortner 2001).

At the methodology about the recreation of the biological profile, the anthropologist should pay attention to those parameters which let him to identify characteristics like sex, age at death, ancestry or height according morphologies of the bones which 


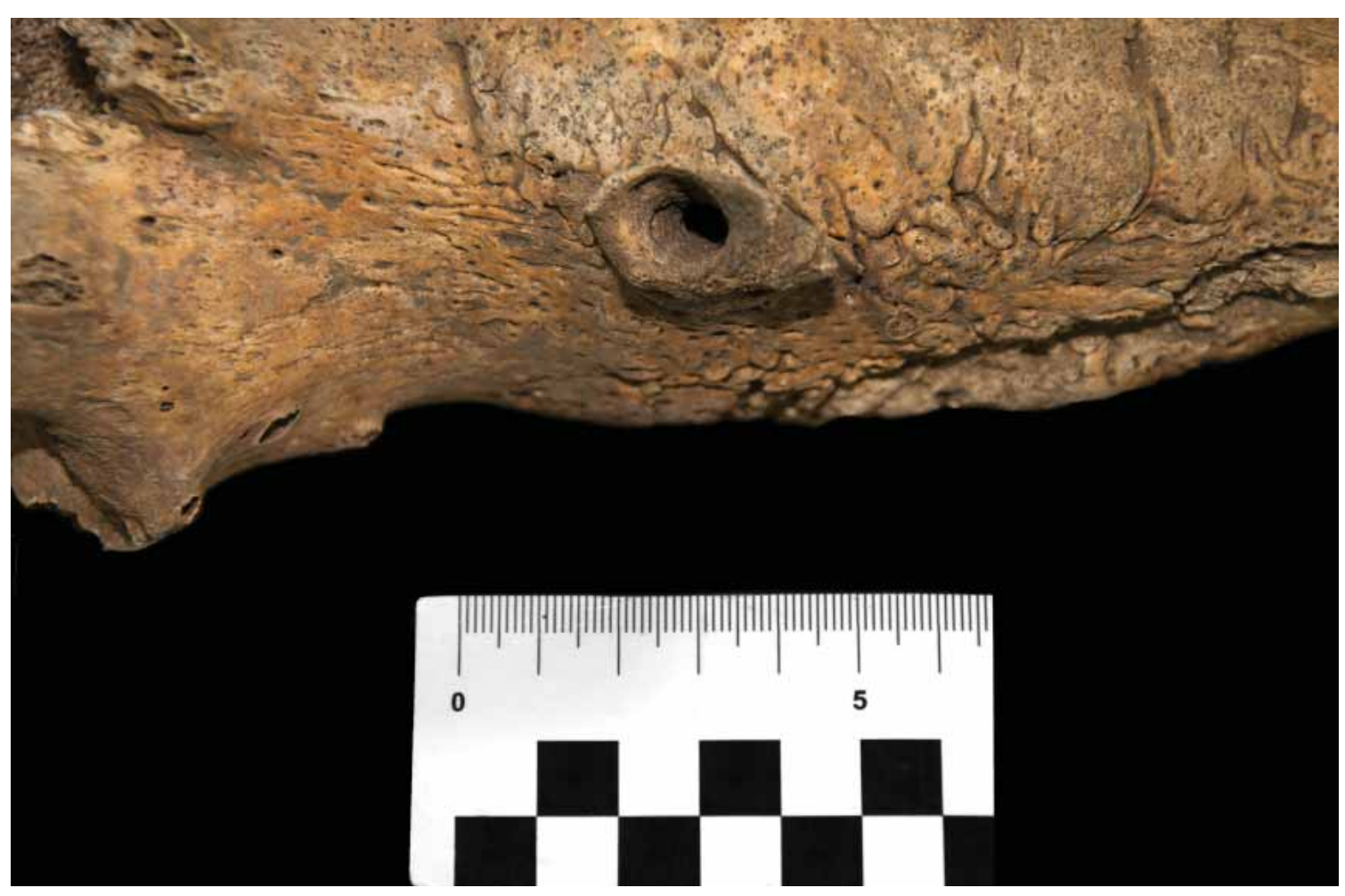

Fig. 2 Detail of the cloaca in left femur.

comprises the skull or pelvic girdle among others.

In this particular case the only bones which have been recovered are those which form both arms and legs (none of the bones from feet or hands bone are present). This situation limit us in order to obtain any information about this topic because we do not have elements to analyse this parameters.

Regarding the methods followed in order to interpret the pathologies and traumas, the macroscopic appearence of the bones gave us information enough in order to determine the main characteristics of the abnormalities shown in several bones.

On one hand, the left femur show us the appearence of a bone afected by an infectious disease: it has a modification of the shape in the lower part of the shaft and the distal part of the femur showing a bloated appearance and cell-shaped bone tissue in the external part along with a cloaca in order to drain the necrotic and purulent material that the bone has in its inner part as a result of the infection.

Also, macroscopically the individual shows modification in the shape of both radius bone as a result of a previous fracture (probably greenstick fractures as a result of a trauma during the youthful) because they presents the possible results of a healing, and the same occurs with the amputation of the left ulna. Finally, factors as the shape, colour, lack of healing process and the alterations that shows the cut in the right femur demonstrate us that the is result of cut very long time after death, probably in recent time..

\section{RESULTS AND DISCUSSION}

Regarding the biological profile, the skeletal representation recovered did not let us obtain more information that it is an individual with more than 20 years when he died because the distal radius and proximal ulna has been fused with the rest of the bone.

In this case we would like to present infection of left femoral bone. Several explanations will be mentioned as possible cause of the infection. The most common case of osteomyelitis is exactly on long bones and this type is known as 


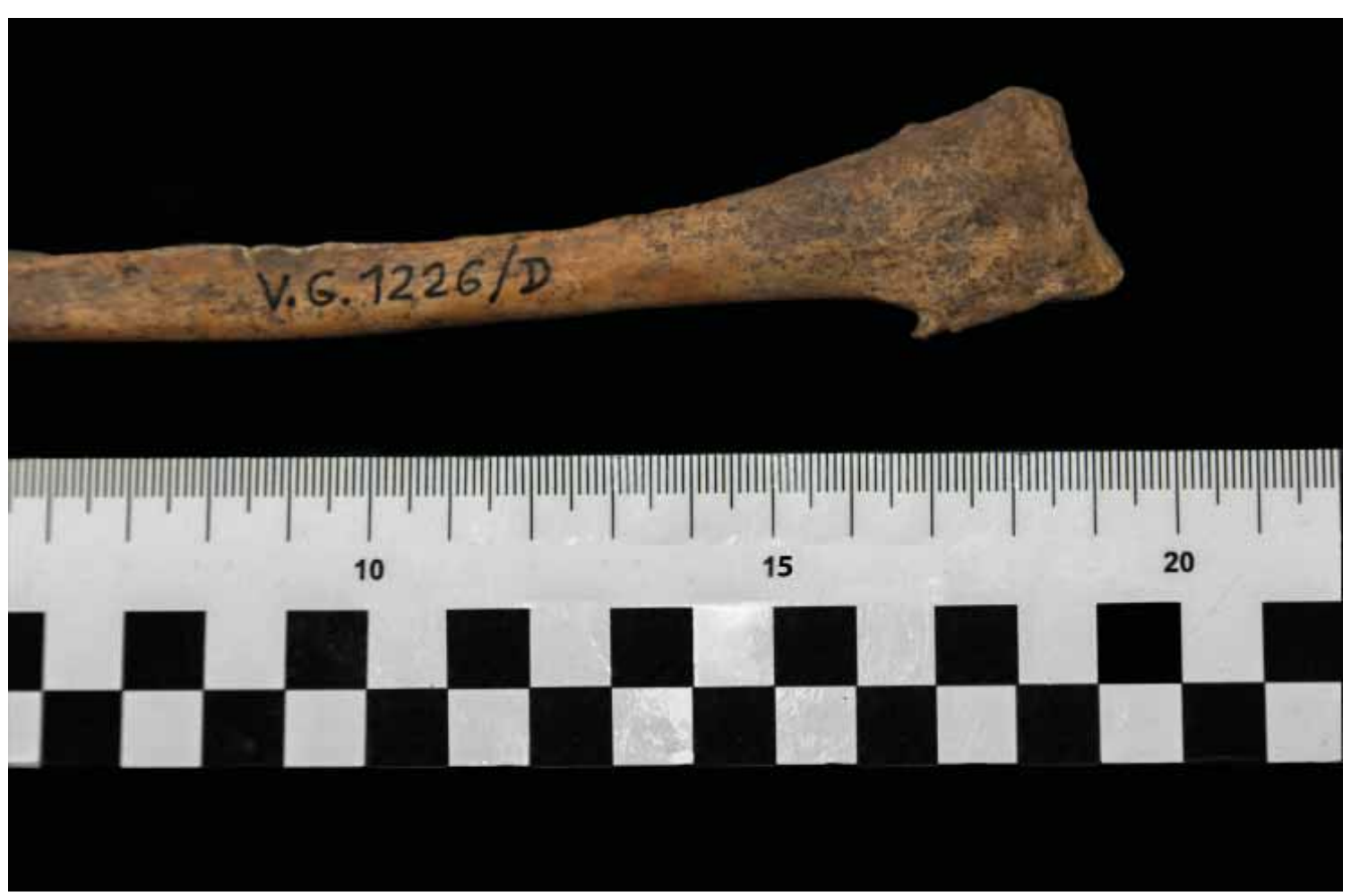

Fig. 3 Greenstick fracture in right radius.

hematogenous osteomyeltis. In $80 \%$ of osteomyelitic cases, the femur and tibia are counted. (Ortner and Putschar 1981; Aufderheide and Rodríguez-Martín 1998).

The results of the infection are cloaca or sequestrum in association with periostal bone known also as involucrum which presents new sheath of bone and growth around sequestrum (Ortner 2001: 214). On the other hand, cases of osteomyelitis can be results of tuberculosis or smallpox. The most common bacteria which can be cause of infection are Staphylococcus Aurea. The second one is Streptococcus.

The conclusion is that osteomyelitis on individual marked as $1226 \mathrm{D}$ was caused probably by infection. It is because probably this person had not adequate medical treatment after trauma or wound. This wound could have been on the femur, or on other bones. On the other hand, in regarding that this person had other traumas on skeleton and that the normal bone is not resistant on this kind of infection, with even greater certainty we can make this conclusion.
Along with the most characteristic pathology that suffered this individual, the osteomyelitis previously described, both radius bones present deformations on its distal part, showing an antemortem healing process, but they did not seem to have been broken completely but presenting bone fissures.

If we focus our attention to the distal part of the left radius we can check that it presents a strong deformation with the change of shape and location of the articular surface for the joint of the wrist. Also, it has lost its primary position, being slightly moved to the medial line, provoking as a consequence the change of position of the hand presenting a deviation from its natural movement, pointing the hand to lateral when the body is in anatomic position.

The radius bone located in the right arm presents also a abnormal shape in the same place. In this particular case it has a growth of new cartilage as a result of healing and the original position has been turned to pointing the joint to the medial part of the body. 


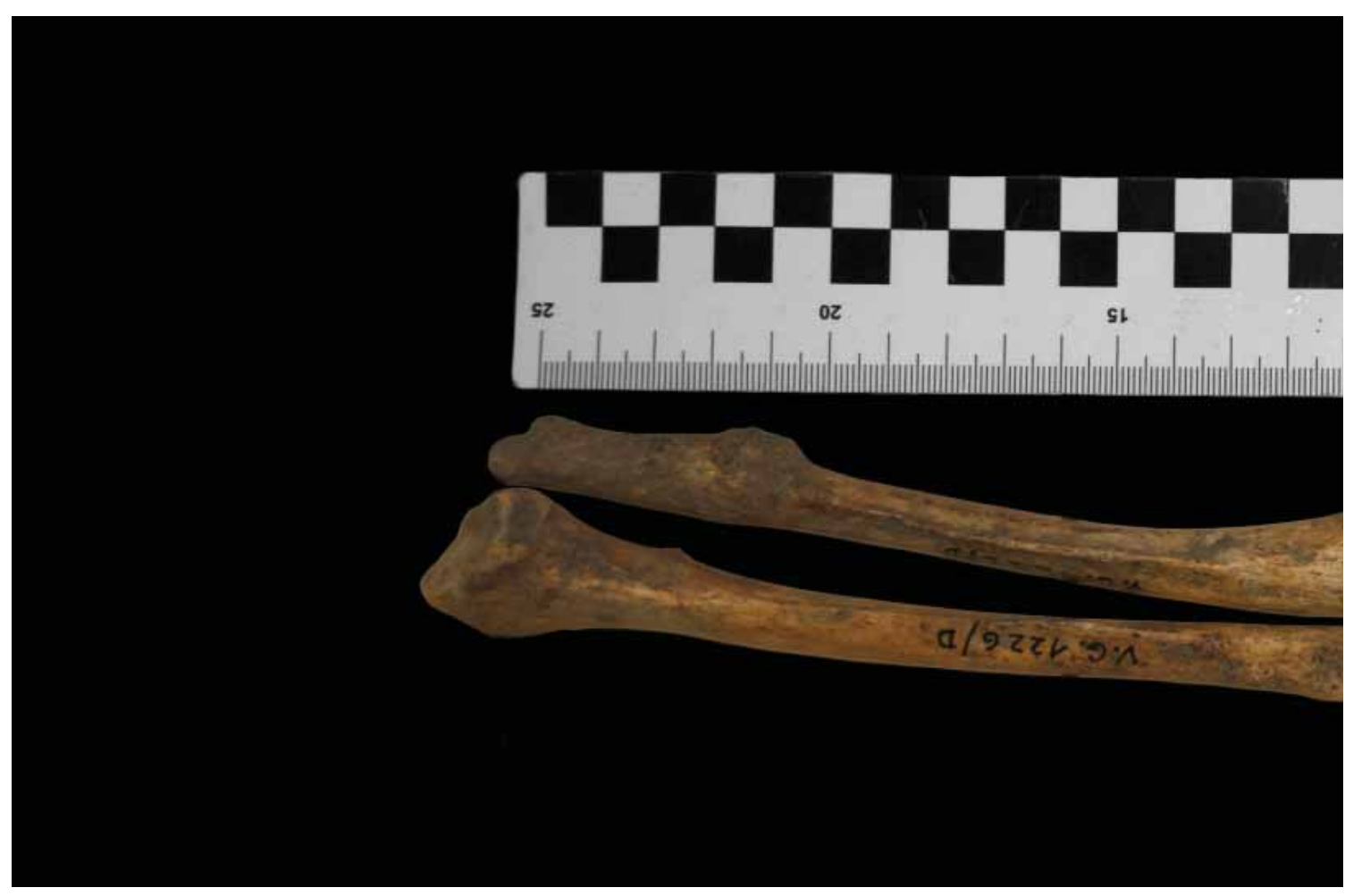

Fig. 4 Greenstick fracture in left radius and amputation in left ulna.

In both cases, it has been created a new bone in form of enthesiophytes as a result of the new stress caused by the change of position of the joint and the creation of new movements in the bones and both seems to have the characteristics of a greenstick fracture as a result of a bending fracture when the individual was in the juvenile period (Ortner and Puschard 2001).

Another factor that change the shape and the use of the left hand is the lost of the continuity of the bone and the posterior healing that the individual shows in the left ulna. It shows an irregular healing, possible medical treatment that was carried out during his life, and it seems to be practiced in the lower part of the shaft of the bone, losing the most part of its distal region and being reabsorbed. It is not possible to know the real afection in the hand because no more bones have been recovered from this part of the body.

Also, as a result, it has been created new bone in the lower part of the shaft of the same ulna in form of enthesiophytes, which means that the joint and the rest of the hand have been seriously affected both the amputation and the modification of the radius bone.

According with the studies carried out by Moodie (Moodie 1920), Brothwell and Moller-Christensen (Brothwell and Moller-Christensen 1963), there are three ways to obtain an amputation: as a result of a surgical amputation, a punitive action against a criminal or captive or injury with a sharp weapon. In this particular case, there is no horizontal cut line but instead it has a fracture that goes from the proximal part of the ulna to its distal part, that has been healed later.

It means that the probability to be the result of one of this options is very low according to the irregular shape that it shows. It is more probable that it was caused by a blunt instrument that broke the bone in an irregular pattern, not affecting to the radius. Also, it means that the bone shards have been medically extracted. On the other hand, it is not possible to check if it has any influence in the hand because it has not been recovered. 


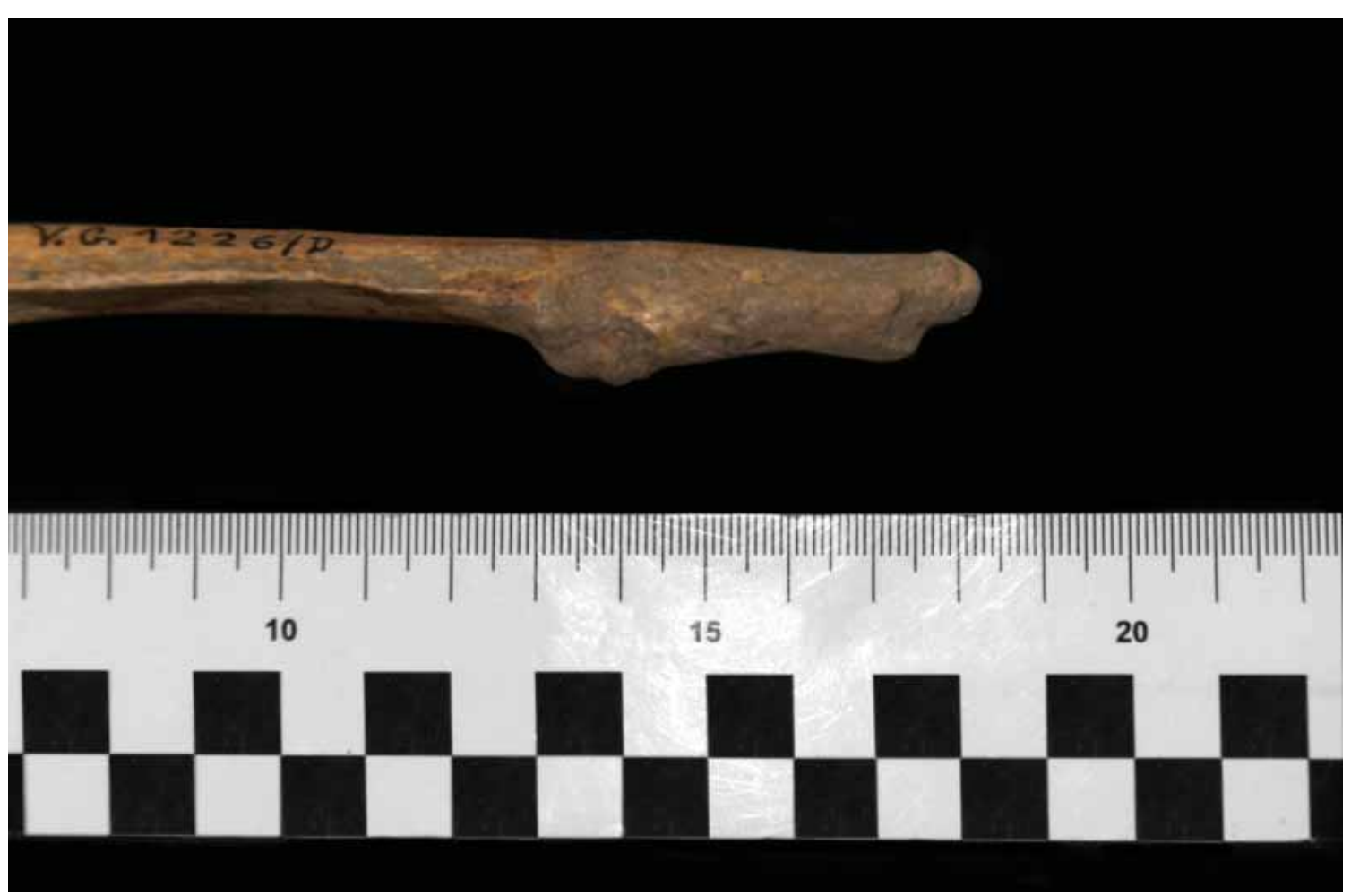

Fig. 5 Detail of the amputation in left ulna.

\section{CONCLUSIONS}

Purulent osteomyelitis and notorious cloaca as result of infection infer that this person did not have adequate medical treatment. Medicine in Roman times was advanced, but insufficient for the treatment of such diseases. Nowadays, this type of infection is treated with antibiotics or surgery. This type of disease is very painful and would have made mobility very difficult.

Because of this, it can be assumed that this person was immobile. This is particularly evident when we take into account the other paleopathological conditions which have already been discussed.

According with the results obtained regarding the traumas, on one hand we have that the individual has broken his radius in a bending fracture but its youth let him to heal them in form of greenstick fractures, provoking a permanent deformation in both hands, being displaced the shape towards the midline of the body.

On the other hand, the healed fracture it presents in the left ulna shows a surgical intervention in the form of an ampitation technically speaking. Part of the bone, the bone sharps, has been removed and after that the healing was correct, afecting at the movement of the wrist.

If we have into consideration the time when this even occur, it is documented that in Roman Times there existed surgeons and physicians able to carry out this operations. The medicians of this culture had sedatives made of a combination of opium and henbane and another antiseptic techniques which helps the recovery and avoid the extraordinary rate of death within this practice. (MacCallum 2008).

Regarding the cut in the right femur and the lack of recovery of any bone from this distal part to the end of the leg shows that it was removed after his death give us one possibility that someone cuted left femoral bone and for sure this is not posmortem amputation.

The shape of the cut shows us a perfect cut with no expansion lines which means that it could be done by a flat and sharp instrument like a some kind of saw. 


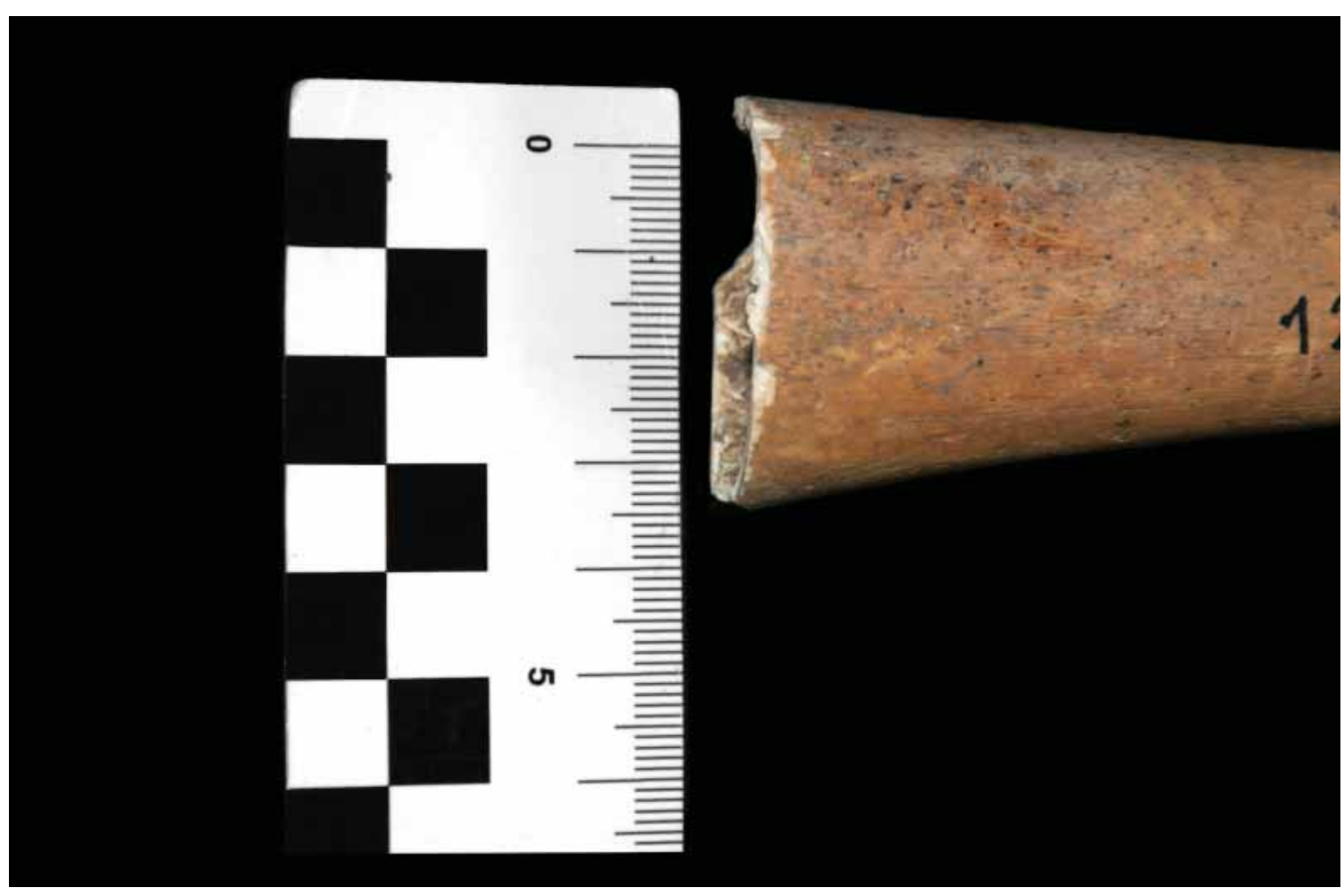

Fig. 6 Detail of the cut in right femur.

\section{BIBLIOGRAPHY}

\section{Brothwell DR, Møller-Christensen V. 1963}

A possible case of amputation, dated to c. 2000 B.C. Man 63: 192-194.

Ferembach, D., Schwidetzky, I. and Stloukal, M. 1980

Recommendation for age and sex diagnoses, Journal of Human Evolution 9, 1980: 517-549.

\section{McCallum, J.E., 2008}

Military Medicine: from Ancient Times to the 21st Century. ABC-CLIO, Inc., Santa Barbara.

\section{Moodie, R. L. 1920}

Amputation of the Finger by Neolithic and Modern Primitive Races, and Other Voluntary Mutilations Indicating Some Knowledge of Surgery. Surgical Clinic of Chicago, 4: 1299-1306.
Ortner, D.J. 2003

Identification of Pathological Conditions in Human Skeletal Remains. Washington: Smithsonian Institution Press.

\section{Ortner, D.J., Putschar, W.G.J. 1981}

Identification of Pathological. Conditions in Human Skeletal Remains. Smithsonian Contributions to Anthropology.

\section{Stuckert, C. M., Kricun, M.E. 2011}

A case of bilateral forefoot amputation from the Romano-British cemetery of Lankhills, Winchester, UK. International Journal of Paleopathology 1: 111-116.

\section{Waldron, T. 2008}

Paleopathology. Cambridge Manual in Archaeology. Ed. Cambridge. 
REZIME

PALEOPATOLOŠKA ANALIZA INDIVIDUE POD OZNAKOM 1226-D IZ NEKROPOLE VIŠE GROBALJA: OSTEOMIJELITIS UZ PRELOME KOSTI I HIRURŠKE INTERVENCIJE

\section{KLJUČNE REČI: PALEOPATOLOGIJA, OSTEOMIJELITIS, AMPUTACIJA, PRELOM KOSTIJU, ANTEMORTEM TRAUMA.}

Tokom arheoloških istraživanja koja su sprovedena na nekropoli Više grobalja na Viminacijumu pronađen je grupni grob pod oznakom G-1226. Sadržavao je ukupno četiri individue, a predmet ovog rada je individua pod oznakom
G-1226D. Zbog slabe i nekompletne očuvanosti, pol nije mogao biti utvrđen, dok je individualna starost oko 35 godina. Paleopatološka analiza je utvrdila postojanje nekoliko promena na skeletu: osteomijelitis na levoj butnoj kosti, obe žbice su bile polomljene kao i leva lakatna kost koja je amputirana. Sa druge strane, desna butna kost je bila odsečena u distalnom delu, ali dugo posle smrti i to je uradjeno verovatno u moderno doba za potrebe uzimanja uzoraka. Ovakvo stanje skeleta pruža pretpostavku da se ova osoba verovatno otežano kretala. Kroz analize nabrojanih paleopatoloških stanja došlo se do zaključka da je medicina u rimsko vreme bila napredna, ali nedovoljno za lečenje komplikovanijih infekcija kao što je to osteomijelitis. 